\title{
Histological and Transcriptional Expression differences between Diabetic Foot and Pressure Ulcers
}

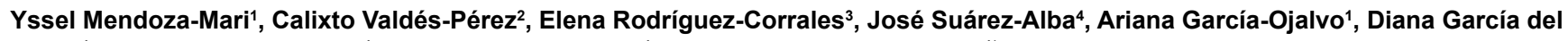
Barco', Gerardo Guillén-Nieto1, Luis Herrera-Martínez ${ }^{1}$ and Jorge Berlanga-Acosta ${ }^{{ }^{*}}$

${ }^{1}$ Wound Healing, Tissue Repair and Cyto-protection Laboratory, Center for Genetic Engineering and Biotechnology, Cuba

${ }^{2}$ Diabetic Angiopathy Ward, National Institute of Angiology and Vascular Surgery, Cuba

${ }^{3}$ Diabetic Angiopathy Ward, National Institute of Dermatology “Dr. Ramón Hernández Vaquero”, Cuba

${ }^{4}$ Department of Pathology, Center for Genetic Engineering and Biotechnology, Cuba

\begin{abstract}
Decubitus and diabetic foot ulcers remain as important clinical challenges with significant socioeconomic impact. Both are individual forms of chronic wounds with diverse proximal ethiopathogenic triggers. This study aimed to characterize and compare the main histological features as the transcriptional expression profile of a set of wound-healing relevant genes of the ulcers' granulation tissue. Following patients' consent, biopsies were collected from sacrolumbar pressure ulcers ( $N=5$, stage IV) and diabetic foot ulcers $(N=9$, both of neuropathic and ischemic origin) with clean, non-infected granulation tissue. Biopsies fragments were processed for histological analysis and for RNA extraction and subsequent transcriptional expression characterization via RT-PCR. The group of targeted genes included cell proliferation control, extracellular matrix, glucose metabolism, anabolismsurvival, as anti-hypoxia and anti-oxidant defense. Gene expression was determined, normalized with an internal housekeeping gene, and statistically compared. Each class of chronic ulcer granulation tissue: decubitus, and diabetics' ischemic and neuropathic proved to develop a particular histological pattern thus establishing individual differences. Moreover, diabetes appeared to significantly reduce the expression of numerous genes irrespective to their biological significance. Most importantly, we found that diabetic granulation tissue cells exhibit a sort of "genetic or epigenetic imprinting" for the expression of glucose-metabolism related genes which are deeply involved in type-2 diabetes pathophysiology. Our data indicate that in addition to a protracted inflammation and abnormal angiogenesis, diabetic granulation tissue cells are affected by gene expression failures that may lead to a negative pro-anabolic and energetic balance.
\end{abstract}

Keywords: Diabetes; Diabetic ulcer; Decubitus ulcer; Wound healing; Chronic ulcer

Abbreviations: PU: Pressure Ulcer; DFU: Diabetic Foot Ulcer; MMP2: Matrix Metallopeptidase 2; MMP9: Matrix Metallopeptidase 9; HIF-1a or HIF1A: Hypoxia Inducible Factor 1, Alpha Subunit; VEGF: Vascular Endotelial Growth Factor; HSP: Heat Shock Protein; ROS: Reactive Oxygen Species; AGE: Advanced Glycation End Products; RAGE: Receptor for Advanced Glycation End Products; FOXO: Forkhead Box Protein O; yrs: years; H/E: Hematoxylin/Eosin; RNA: Ribonucleic Acid; EGFR: Receptor for Epidermic Growth Factor; AKT1: Human v-akt Murine Thymoma Viral Oncogene Homolog 1; PIK3CA: Phosphatidylinositol-4,5-bisphosphate 3-Kinase, Catalytic Subunit Alpha; PTEN: Phosphatase and Tensin Homolog; MTOR: Mechanistic Target of Rapamycin; CCND1: Cyclin D1; CDK4: Cyclin-dependent Kinase 4; PCNA: Proliferating Cell Nuclear Antigen; RB1: Retinoblastoma 1; E2F1: E2F Transcription Factor 1; MYC: v-myc Avian Myelocytomatosis Viral Oncogene Homolog; TP53: Tumor Protein p53; COL1A1: Collagen, Type I, Alpha 1; COL3A1: Collagen, Type III, Alpha 1; TGFB1: Transforming Growth Factor, Beta 1; ILK: Integrin-Linked Kinase; INSR: Insulin Receptor; SLC2A1: Solute Carrier Family 2 (facilitated glucose transporter), Member 1; HK1: Hexokinase 1; HK2: Hexokinase 2; PFKP: Phosphofructokinase, Platelet; PKM: Pyruvate Kinase, Muscle; PDHA1: Pyruvate Dehydrogenase (lipoamide) Alpha 1; PDK4: Pyruvate Dehydrogenase Kinase, Isozyme 4; PPARG: Peroxisome Proliferator-Activated Receptor Gamma; PPARGC1: Peroxisome Proliferator-Activated Receptor Gamma, Coactivator 1 Alpha; SIRT1: Sirtuin 1; SOD2: Superoxide Dismutase 2, Mitochondrial; TNF: Tumor Necrosis Factor; RNA18S1: RNA, 18S Ribosomal 1

\section{Introduction}

Pressure or decubitus ulcers (PU) and diabetic foot ulcers (DFU) are among the most common chronic wounds representing individual clinical entities but sharing a significant socioeconomic impact [1]. These chronic ulcers translate in systemic repercussion as they may act as pro-inflammatory and pro-oxidant organs super-imposed to a host that could evolve to a chronic low-grade inflammatory response [2].

Pressure ulcers continue to be a worldwide common health problem, particularly among the neurologically impaired or bedridden elderly. Its medical history dates back to the renaissance when the French surgeon Ambrose Paré enlisted; nutrition, pain relief and debridement as key factors to heal these ulcers. Surprisingly, it is not quite different than the present modality to some extent [3]. To date, a large percent of grades 3 and 4 pressure ulcers evolve to chronification and lead the patient to death due to ulcer complications such as sepsis or osteomyelitis [4].

*Corresponding author: Jorge Berlanga-Acosta, Wound Healing and CytoProtection Research Group, Biomedical Research Direction, Center for Genetic Engineering and Biotechnology, Havana 10600, PO Box: 6162, Havana, Cuba, Tel: 53-7-271 60 22; Fax: 53-7-250 44 94; E-mail: jorge.berlanga@cigb.edu.cu

Received September 02, 2013; Accepted October 07, 2013; Published October 12, 2013

Citation: Mendoza-Mari Y, Valdés-Pérez C, Rodríguez-Corrales E, Suárez-Alba J, García-Ojalvo A, et al. (2013) Histological and Transcriptional Expression differences between Diabetic Foot and Pressure Ulcers. J Diabetes Metab 4: 296. doi:10.4172/2155-6156.1000296

Copyright: (c) 2013 Mendoza-Mari Y, et al. This is an open-access article distributed under the terms of the Creative Commons Attribution License, which permits unrestricted use, distribution, and reproduction in any medium, provided the original author and source are credited. 
Citation: Mendoza-Mari Y, Valdés-Pérez C, Rodríguez-Corrales E, Suárez-Alba J, García-Ojalvo A, et al. (2013) Histological and Transcriptional Expression differences between Diabetic Foot and Pressure Ulcers. J Diabetes Metab 4: 296. doi:10.4172/2155-6156.1000296

From the ethiopathogenic perspective, cutaneous ischemia appears to be the proximal trigger of a downstream cascade of molecular events that converge to impose a chronic evolution. These include the overactivation of molecular regulators toward a pro-apoptotic program [5], imbalance in matrix metalloproteinases regulation (MMP2 and MMP9) [6], and adhesion molecules overexpression [7]. At the experimental level, a reduction of the cutaneous cells constitutive expression of endogenous cytoprotective molecules such as hypoxia-inducible factor-1 alpha (HIF-1 $\alpha$ ), VEGF, HSP 70 and 90 and hemeoxigenase-1 [8] have been demonstrated. Despite the medical and social problem that the pressure ulcer represents, still remains a paucity of data aimed to characterize its molecular pathophysiology in clinical samples.

Within the diabetic context, hyperglycemia stands as the proximal ethiopathogenic trigger for the onset and progression of biochemical disturbances that steers the systemic complications, in which ulcer healing failure and amputation are included. The vicious circle between wound chronicity and deficient local infection control, determines that $85 \%$ of all non-traumatic lower extremity amputations are rendered by diabetic subjects [9]. At the molecular level, this high glucose burden unleashes acute and chronic self-perpetuating loops, which include ROS-lipid peroxidation, hyperinflammation/disimmunity, AGERAGE toxicity, mitochondrial dysfunction, nytrosilation end-products accumulation, FOXO genes deregulation and a perspicuous reduction of growth factors physiology. The concerted action of these elements enforces granulation tissue-producing cells to senescence, arrest and apoptosis. Furthermore, the failure of the agonistic stimulation of the insulin axis and other tyrosine kinase receptors, negatively impacts on the biology of diabetic wound cells [10].

This study intends to be a modest contribution to the characterization of the chronic wound microenvironment, by characterizing and comparing granulation tissue samples histology, as the gene expression profiles in these two common and devastating types of human chronic wounds.

\section{Experimental Procedures}

\section{Population and study enrollment criteria}

The enrollment of patients was based on the following criteria addressed to preserve as "clean" as possible the experimental substrate for a neat constitutive gene expression profile. Diabetic co-morbids and pressure ulcer-affected patients with concurrent clinical conditions, requiring medication that we understood as potentially gene expression modifiers were not enrolled in the study. Thus, for diabetics, only those with oral hypoglycemic treatment were sampled. Insulin-dependent and uncompensated patients were not included. Furthermore, patients with clinical depression, heart failure, renal insufficiency, unstable angina, asthma, angiotensin-converting-enzyme inhibitors-medicated, and subjects with auto-immune processes were excluded. As all the pressure ulcer samples population had a spinal injury (lumbar segment) as the primary process, the only subjects included were those free of lower limbs hyperspastic episodes, simply receiving physical therapy/postural rotation and no pharmacological intervention. Obviously, patients with malignant diseases and history of chemotherapy were discarded. No pregnant or breast feeding women were conceived to be included.

All the patients were consulted about the experimental procedure and approved to offer a biopsy fragment for the study. For the chronic wounds, the granulation tissue fragment was obtained from a productive area, with no macroscopic evidence of infection, during a routine wound debridement and cleansing. The investigation material was collected from: (1) sacrolumbar pressure ulcers (stage IV) from nonemaciated patients with history of spinal trauma [11], and (2) diabetic foot ulcers of both neuropathic and ischemic origin from reasonably compensated in-hospital patients [12]. As control of an acute wound we used a fragment derived from granulation tissue, obtained from a healthy female donor (20-yrs old) who experienced wound dehiscence following esthetic breast surgery. The sample was collected during the final surgical wound closure when the exuberant granulation was trimmed.

\section{Tissue processing}

Six-millimeter diameter punch biopsies were collected days after a series of surgical debridements and ulcers bed preparation, as part of the standard wound care procedures; using disposable sterile biotomes (Acuderm Inc., USA), washed in normal saline to remove blood and immediately hemisectioned along its longitudinal axis. A hemisection was fixed in $10 \%$ buffered formalin, horizontally paraffin-embedded, processed, and 5- $\mu \mathrm{m}$ slides stained with $\mathrm{H} / \mathrm{E}$ and Mallory trichrome for a better definition of collagen accumulation. The other hemisection was preserved in RNA later solution (Ambion, Life Technologies, USA) and processed for gene expression analysis.

\section{Gene expression analyses by semiquantitative RT-PCR}

Total RNA was purified according to TRI Reagent standard procedure (Sigma, USA), followed digestion with RQ1 DNase I (Promega, USA) to remove contaminating genomic DNA. Afterward, 500 nanograms of DNA-free RNA were reverse transcribed using a commercial available kit (Omniscript RT, Qiagen, Germany) with oligo-dT primer. The RT reaction was performed at $42^{\circ} \mathrm{C}$ for $60 \mathrm{~min}$. PCR mixtures contained $2 \mu \mathrm{L}$ cDNA, $1 \mu \mathrm{L}$ of each primer $(10 \mu \mathrm{M})$, $12.5 \mu \mathrm{L} 2 \mathrm{X}$ Taq MasterMix (Qiagen, Germany) in a final volume of $25 \mu \mathrm{L}$. Specific sense and antisense primers, annealing temperatures and number of repeating cycles are referred in Table 1. Amplifying conditions were performed as followed: a first step of $95^{\circ} \mathrm{C}$ for 5 minutes, thereafter repeating cycles comprised of $95^{\circ} \mathrm{C}$ for 30 seconds, specific annealing temperature for 30 seconds and $72^{\circ} \mathrm{C}$ for 30 seconds, and a final extension step of 5 minutes at $72^{\circ} \mathrm{C}$. PCR bands $(8 \mu \mathrm{L}$ of PCR product with $2 \mu \mathrm{L}$ of gel loading buffer) were resolved on a $1.5 \%$ $(w / v)$ agarose gel electrophoresis and visualized under ultraviolet light subsequent to being stained with ethidium bromide. PCR products were quantified using the Kodak ID 3.6 software package (Kodak Inc, USA). Ribosomal subunit $18 \mathrm{~S}$ was used as housekeeping gene for normalization. Despite the broad spectrum of biological functions of some of the genes studied, for practical reasons we have grouped them as follows:

1. Genes involved in signaling pathways: EGFR, AKT1, PIK3CA, PTEN, MTOR

2. Genes involved in cell proliferation control: CCND1, CDK4, PCNA, RB1, E2F1, MYC, TP53

3. Genes involved in extracellular matrix biology: COL1A1, COL3A1, TGFB1, ILK

4. Genes involved in glucose metabolic pathways: INSR, SLC2A1, HK1, HK2, PFKP, PKM1, PKM2, PDHA1, PDK4

5. Genes involved in survival and anabolism: FOXO1, FOXO3, PPARG, PPARGC1, SIRT1

6. Anti-oxidant and anti-hypoxia defense: SOD2, HIF1A

7. Pro-inflammatory: TNF

8. Housekeeping gene: RNA18S1 
Citation: Mendoza-Mari Y, Valdés-Pérez C, Rodríguez-Corrales E, Suárez-Alba J, García-Ojalvo A, et al. (2013) Histological and Transcriptional Expression differences between Diabetic Foot and Pressure Ulcers. J Diabetes Metab 4: 296. doi:10.4172/2155-6156.1000296

Page 3 of 11

\begin{tabular}{|c|c|c|c|c|c|c|c|}
\hline Gene & Approved symbol & $\begin{array}{c}\text { Gene Bank accession } \\
\text { number }\end{array}$ & & Primer sequence & $\operatorname{Tm}\left({ }^{\circ} \mathrm{C}\right)$ & $\begin{array}{l}\text { No. } \\
\text { cycles }\end{array}$ & Product length (bp) \\
\hline EGFR & EGFR & NM_005228.3 & $\begin{array}{c}\text { sense } \\
\text { antisense }\end{array}$ & $\begin{array}{l}\text { CAGCAGAGACCCACACTACCAG } \\
\text { GAGCCCTTAAAGATGCCATTTGG }\end{array}$ & 58 & 35 & 213 \\
\hline \multirow[t]{2}{*}{ Akt } & \multirow[t]{2}{*}{ AKT1 } & \multirow[t]{2}{*}{ NM_005163.2 } & sense & ACAAGGACGGGCACATTAAGAT & \multirow{2}{*}{62} & \multirow[t]{2}{*}{35} & \multirow[t]{2}{*}{189} \\
\hline & & & antisense & GACCGCACATCATCTCGTACAT & & & \\
\hline $\mathrm{PI} 3 \mathrm{~K}$ & PIK3CA & NM_006218.2 & sense & IGGIGAAAGACGAIGGACAACI & 54 & 35 & 151 \\
\hline & & & sense & CAATCCTCAGTTTGTGGTCTGC & & & \\
\hline PTEN & PTEN & NM_000314.4 & antisense & GGTTTCCTCTGGTCCTGGTATG & 54 & 35 & 226 \\
\hline mTOR & MTOR & NM 004958.3 & sense & GGGACTGCTTTGAGGTTGCTAT & 56 & 35 & 249 \\
\hline & & & antisense & ATCGCTTGTTGCCTTTGGTATT & & & \\
\hline Cyclin D1 & CCND1 & NM 053056.2 & sense & ССССАACAАСТTCСТGTCCTAC & 60 & 35 & 186 \\
\hline & & & $\begin{array}{c}\text { antisense } \\
\text { sense }\end{array}$ & $\begin{array}{l}\text { АССТССТССТССТССТСТТССТ } \\
\text { СGAAACGATCAAGGATCTGATTG }\end{array}$ & & & \\
\hline CDK4 & CDK4 & NM_000075.3 & antisense & TAACAACCACGGGTGTAAGTGC & 55 & 35 & 188 \\
\hline PCNA & PCNA & NM 02592 ? & sense & TCAGCCATATTGGAGATGCTGT & 55 & 35 & 228 \\
\hline TUNA & PCNA & INIII_O0Z2592.2 & antisense & GTGTCACCGTTGAAGAGAGTGG & 55 & 35 & $2 \angle 8$ \\
\hline $\mathrm{RB}$ & RB1 & NM 0003212 & sense & ССССТACCTTGTCACCAATACC & 62 & 35 & 246 \\
\hline RB & RBT & NM_000327.2 & antisense & CACGGTCGCTGTTACATACCAT & 62 & 35 & 246 \\
\hline E2F1 & E2F1 & NM 0052252 & sense & CGTGGACTCTTCGGAGAACTTT & 58 & 35 & 187 \\
\hline $\mathrm{E} 2 \mathrm{~F} T$ & $\mathrm{E} 2 \mathrm{~F} 1$ & NM_005225.2 & antisense & AGATGATGGTGGTGGTGACACT & 58 & 35 & 181 \\
\hline c-mvc & MYC & NM 0024674 & sense & TCCACACATCAGCACAACTACG & 58 & 35 & 171 \\
\hline c-myc & & & antisense & GTGTGTTCGCCTCTTGACATTC & 58 & 35 & $1 / 1$ \\
\hline 053 & TP53 & NM 0005464 & sense & TTGGCTCTGACTGTACCACCAT & 56 & 35 & 203 \\
\hline p53 & IP53 & NM_000546.4 & antisense & TTTCTTGCGGAGATTCTCTTCC & 56 & 35 & 203 \\
\hline Collagen 1 & COL1A1 & NM 0000883 & sense & CCAGAACATCACCTACCACTGC & 60 & 35 & 218 \\
\hline & & & antisense & GGGAGGTCTTGGTGGTTTTGTA & 60 & 35 & \\
\hline Collaron & COI $3 \Delta 1$ & NM 0000003 & sense & TGCAAATTGGATGCTATCAAGG & 56 & 35 & 205 \\
\hline Collagen III & COLSAT & NIII_O00090.3 & antisense & GCACATCAAGGACATCTTCAGG & 56 & 35 & 205 \\
\hline TGF $\beta 1$ & TGFB1 & NM 0006604 & sense & ACAATTCCTGGCGATACCTCAG & 58 & 35 & 196 \\
\hline$T G F \beta 1$ & IGFB1 & NM_000660.4 & antisense & GTAGTGAACCCGTTGATGTCCA & 58 & 35 & 196 \\
\hline$\| K$ & $\| K$ & 14402821 & sense & GCATGGCTGATGTCAAGTTCTC & 56 & 35 & 156 \\
\hline ILK & ILK & 040282.1 & antisense & GTGTCACCAGTTCCCACAGAAG & & 35 & 156 \\
\hline Glut1 & SLC2A1 & NM 0065162 & sense & ACCCTGGATGTCCTATCTGAGC & 58 & 35 & 360 \\
\hline & SLC2A1 & NIM_006516.2 & antisense & TCCTCGGGTGTCTTGTCACTT & 58 & 35 & 360 \\
\hline Insulin Receptor & INSR & M10051.1 & sense & TGTCATGGATGGAGGGTATCTG & 56 & 35 & 174 \\
\hline & INSR & M10051.1 & antisense & CTGTGGAAGAACGACACCTCTG & 56 & & \\
\hline Hexokinase I & HK1 & NM 000188.2 & sense & CCTAAATGCTGGGAAACAAAGG & 58 & 35 & 193 \\
\hline & & & antisense & CAGTGCTAATCGGTCACTCTCG & 58 & & \\
\hline Hexokinase II & HK2 & NM 000189.4 & sense & ACCAAGCGTGGACTACTCTTCC & 58 & 35 & 156 \\
\hline & 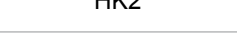 & & antisense & ACAGGTGCTCTCAAGCCCTAAG & 58 & & \\
\hline PEK & PEKP & AM 0026274 & sense & TGGAGTGGATCACTGCAAAACT & 54 & 35 & 165 \\
\hline PFK & PFKP & NIII_002627.4 & antisense & GTTCTTTGGGAATCCTGTGCTC & 54 & 35 & 165 \\
\hline PKM1 & PKM & NM 1824702 & sense & GAGCCTCAAGTCACTCCACAGA & 58 & 35 & 227 \\
\hline & PKIVI & NM_1824/0.2 & antisense & CTTGCACAGCACAGGGAAGAT & 58 & 35 & 227 \\
\hline PKM? & PKM & NM 0026544 & sense & AGAGGCTGCCATCTACCACTTG & 58 & 35 & 150 \\
\hline & & NMI_002654.4 & antisense & CCAGACTTGGTGAGGACGATTA & & & \\
\hline $\mathrm{PDH}$ & PDHA1 & NM 0002843 & sense & AAGAGAGGCGATTTCATTCCTG & 56 & 35 & 248 \\
\hline & PDHAT & NMI_000284.3 & antisense & TTCACCATCCTGTCCTTGAGAA & 56 & 35 & 248 \\
\hline PDK4 & PDK 4 & NM 0026123 & sense & TCCAGACCAACCAATTCACATC & 56 & 35 & 194 \\
\hline & & & antisense & GAACACCACCTCСТCTGTCTGA & 56 & & \\
\hline FOXO1 & FOXO1 & NM 002015.3 & sense & СCTGACCCAAGTGAAGACACCT & 56 & 35 & 159 \\
\hline & FUXU1 & INIII_O0ZU15.3 & antisense & ATGAACATGCCATCCAAGTCAC & 56 & 35 & 159 \\
\hline FOXO3 & FOXO3 & NM 0014553 & sense & СTCTCTCTCAGGCTCCTCCTTG & 56 & 35 & 215 \\
\hline & & & antisense & CCACGTTCAAACCAACAACATT & 56 & & \\
\hline PPAP & PPARG & NM 1387123 & sense & AGATGACAGCGACTTGGCAATA & 56 & 35 & 207 \\
\hline PPAR Y & PPARG & NIII_T38/12.3 & antisense & TCCGTGACAATCTGTCTGAGGT & 56 & 35 & 207 \\
\hline PGC1 $\alpha$ & PPARGC1A & & sense & GCCGTGTGATTTATGTCGGTAA & 56 & 35 & 237 \\
\hline & PFARGLIA & NM_013261.3 & antisense & GCTTGCGTCCACAAAAGTACAG & 56 & 35 & 237 \\
\hline SIRT-1 & SIRT1 & NM 0011424981 & sense & GCAGATTAGTAGGCGGCTTGAT & 56 & 35 & 153 \\
\hline & & & antisense & CTCTGGCATGTCCCACTATCAC & & & \\
\hline Mn-SOD & SOD2 & X143221 & sense & CTGCATCTGTTGGTGTCCAAG & 56 & 35 & 160 \\
\hline & SOD2 & $X 14322.1$ & antisense & TAGTAAGCGTGCTCCCACACAT & 56 & 35 & 160 \\
\hline HIF-1 g & HIF1A & NM 0015303 & sense & TACTCAAAGTCGGACAGCCTCA & 54 & 35 & 179 \\
\hline & & & antisense & TTCGCTTTCTCTGAGCATTCTG & 54 & & \\
\hline TNF- $\alpha$ & TNF & NM 000594.3 & sense & CCATGTTGTAGCAAACCCTCAA & 58 & 35 & 155 \\
\hline & & & antisense & CCTTGAAGAGGACCTGGGAGTA & & & \\
\hline $18 \mathrm{~S}$ & RNA18S1 & M10098 1 & sense & GTAACCCGTTGAACCCCATT & 62 & 30 & 151 \\
\hline & & & antisense & CCATCCAATCGGTAGTAGCG & & & \\
\hline
\end{tabular}

Table 1: Genes investigated and amplification data 
Citation: Mendoza-Mari Y, Valdés-Pérez C, Rodríguez-Corrales E, Suárez-Alba J, García-Ojalvo A, et al. (2013) Histological and Transcriptional Expression differences between Diabetic Foot and Pressure Ulcers. J Diabetes Metab 4: 296. doi:10.4172/2155-6156.1000296

Page 4 of 11

\begin{tabular}{|c|c|c|}
\hline Variable & Diabetic foot ulcers (DFU) & $\begin{array}{l}\text { Pressure ulcers } \\
\text { (PU) }\end{array}$ \\
\hline Age (years; mean $\pm \mathrm{SD}$ ) & $60.1 \pm 15.4$ & $46.2 \pm 14.6$ \\
\hline Male & $6(66.7 \%)$ & $6(100 \%)$ \\
\hline Female & $3(33.3 \%)$ & - \\
\hline Ethnicity & All mixed Afro-Cuban & All white Latin/Hispanic \\
\hline Basic disease duration (yrs, mean; range) & $15.8(0.1-30)$ & $5.9(0.6-19)$ \\
\hline Glycemia level & $\begin{array}{c}7.3 \pm 1.17 \mathrm{mmol} / \mathrm{L} \text { ulcer sampling time } \\
\mathrm{HbA} 1 \mathrm{c} 7.12 \pm 1.55 \%\end{array}$ & $\begin{array}{c}3.11 \pm 0.91 \mathrm{mmol} / \mathrm{L} \text { ulcer sampling time } \\
\mathrm{HbA} 1 \mathrm{c}: \mathrm{ND}\end{array}$ \\
\hline $\begin{array}{l}\text { Ulcer duration (in days) } \\
\text { (mean; range) }\end{array}$ & $50(36-195)$ & $180(60-540)$ \\
\hline Ethiopathogenic classification & $\begin{array}{c}5 \text { ischemics } \\
4 \text { neuropathics }\end{array}$ & Not applicable \\
\hline $\begin{array}{c}\text { Classification (University of Texas DFU scale and } \\
\text { NPUAP* staging, respectively) }\end{array}$ & $\begin{array}{l}\text { Grade 3. Stage C: } 3 \text { patients } \\
\text { Grade } 2 \text {. Stage C: } 2 \text { patients } \\
\text { Grade 2. Stage A: } 3 \text { patients } \\
\text { Grade } 3 \text {. Stage A: } 1 \text { patient }\end{array}$ & stage IV \\
\hline
\end{tabular}

NPAUP: National Pressure Ulcer Advisory Panel (United States of America). Stage IV: Full thickness wound with bone, tendon or muscle exposed/damaged.

HbA1c: Glycated Hemoglobin; ND: Not Determined.

University of Texas Classification for DFUs:

Grade 2: Wound penetrating to tendon or capsule.

Grade 3: Wound penetrating to bone or joint.

Stage A: Non-infected and non-ischemic wound

Stage C: Non-infected, ischemic wound.

Table 2: Demographic characteristic of the chronic ulcers-affected patients.

\section{Statistical analysis}

Statistical analysis of normalized values was carried out using GraphPad Prism 6 for Windows, version 6.01. For gene expression data, normal distribution (Kolmogorov-Smirnov) and variance homogeneity (Brown-Forsythe) tests were performed. Once normality was demonstrated, differences between pressure and diabetic foot ulcers for each gene were analyzed using two-tailed unpaired Student's t-test. In all cases, $p$-values $<0.05$ were considered statistically significant. The values shown represent mean \pm S.D. (error bars).

\section{Results}

\section{Demographic characterization of the study population}

As shown in Table 2, diabetic foot granulation tissue donors included both genders; in contrast, pressure ulcers samples were solely from male patients who had suffered spine compressive traumas. Although the study population is small, the racial profile is representative of the Cuban ethnicity and for the case of diabetics; the basic disease duration almost tripled the one detected for pressure ulcers. Thus, we succeeded in confronting a substrate of chronicity for the basic disease as for the wounds evolution age. As for the later, all the wounds studied met clinical criteria of non-infection, chronicity given the ulcer bed heterogeneity, and of complexity given the strata depth involvement as illustrated by the grades and stage of each classification scale. Importantly, diabetics' derived samples included the most important ethiopathogenic classes: neuropathics and ischemics (above 0.5 ankle-brachial index). Furthermore, the samples were taken from a selected population of relatively well-compensated subjects in which at least the acute effects of a hyperglycemic burden may not be an interference factor for gene expression studies. We also ensured to include only pressure ulcer patients with normal glycemia. All these measures, although somewhat tended to reduce the sample size, were necessary to render confident experimental data.

\section{Histological imprinting in pressure and diabetic foot ulcers}

Pressure ulcers, ischemic and neuropathic diabetic foot ulcers show particular histological aspects that seem to distinguish each of these lesions. The granulation tissue sections from the group of pressure ulcers appeared characterized by the presence of thick, densely packed, wavy, and Mallory positive collagen fibers. Scattered fat vacuoles embedded within the granulation tissue were seen along with an outsized hyperplasic epidermal layer at the wound edge indicating epithelial edge migration abortion. Moreover two main qualitative findings appeared notorious: (1) the limited amount of immunoinflammatory cells infiltrating the granulation tissue as compared to other forms of chronic wounds, and (2) the relative scarcity of fibroblasts in relation to the amount and density of the collagen deposited. The fibroblasts population appeared polarized within the field of evolving collagen bundles. In other microscopic fields, closer to the wound surface, irreversible nuclear changes in fibroblasts were distinguished (Figure 1A and 1B). Ischemic diabetic foot ulcers-derived granulation tissue exhibited the onset of a matrix of hyaline aspect and general scarceness of functional neovessels. An impressive constellation of neo-angiogenesis defects appears since early stages which can be described as: endothelial cells co-opting failure, precocious thickening of vascular wall with hypertrophic tunica media, endothelial cells nuclei hypertrophy, perivascular collagenization, venular lumen collapse, and thick fibrin-like perivascular cuffs. Furthermore a diffuse infiltration of mononuclear cells was observed. Some of these features are shown in Figure 1C. In sharp contrast to the ischemic ulcers-derived material, neuropathic lesions appeared to granulate earlier; exhibiting a poor collagen deposition as a relatively reduced density of extracellular matrix-producing cells (Figure 1D). These neuropathic ulcers matrix often provided the image of a spider web, made up by thin collagen fibers that weakly reacted to Mallory staining. Definitively a substantial difference between both types of wound extracellular matrix was observed. As opposed to ischemic ulcers, a large number of small capillaries were observed, often with endothelial hypertrophy and/ or peripheral fibrin cuffs suggesting hyperpermeability. As noted for ischemic diabetic ulcers, these wounds also exhibited an abnormal, mixed inflammatory infiltration. 
Citation: Mendoza-Mari Y, Valdés-Pérez C, Rodríguez-Corrales E, Suárez-Alba J, García-Ojalvo A, et al. (2013) Histological and Transcriptional Expression differences between Diabetic Foot and Pressure Ulcers. J Diabetes Metab 4: 296. doi:10.4172/2155-6156.1000296
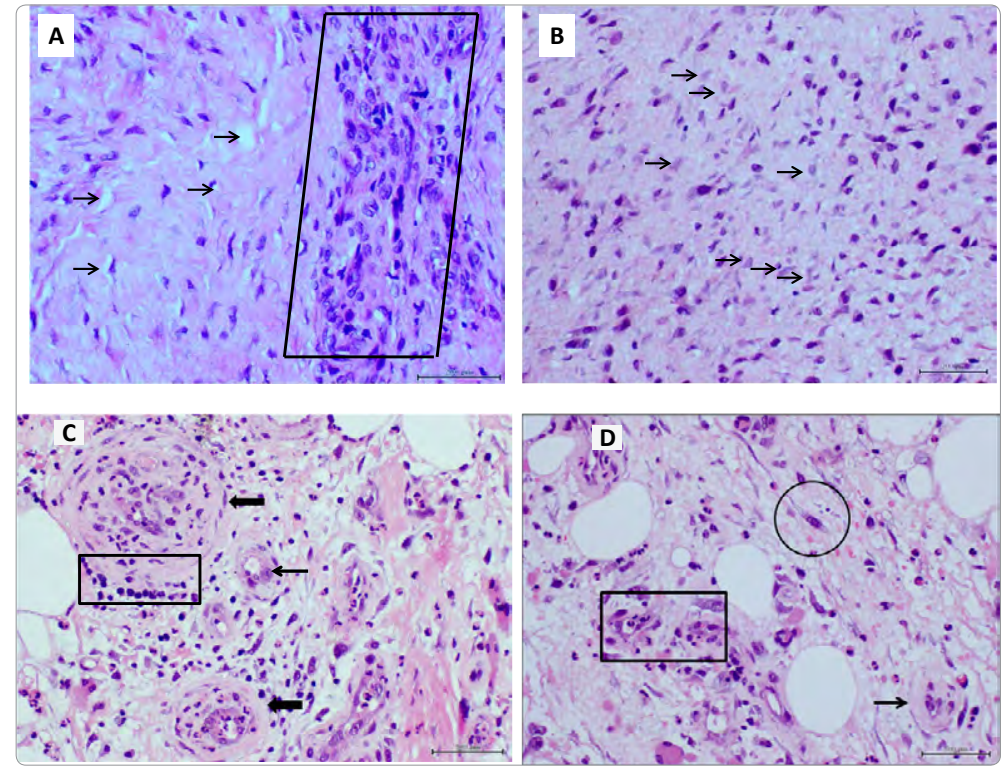

Figure 1 A,B: Histological aspect of pressure ulcers granulation tissue.

Panel A: Within the frame it is shown a column of cells representative of the organization of a thick collagen cord. To the left side of the frame a well-packed collagen matrix is shown with relative acellularity. Arrows indicate the presence of some disperse vacuoles. Magnification $x 40, \mathrm{H} \& \mathrm{E}$

Panel B: It shows a collagen matrix with a different aspect to that in panel A. It appears less dense and collagen bundles are not so wavy. Vacuoles are scarce. Note where the arrows, however, the abundant number of cells (possibly fibroblasts) which have lost hematoxylin basophilic affinity, suggesting an irreversible nuclear damage. Magnification x 40, H\&E

Figure 1C: Histological aspect of granulation tissue of an ischemic diabetic foot ulcer.

Note the precocious onset of vascular anomalies including wall thickening (thick arrows) and endothelial cells nuclear hypertrophy (thin arrows) within an ischemic granulation tissue of about 10 days. An immuno-inflammatory infiltrate by round cells is typical of these types of wounds (frame). Magnification $\mathrm{x} 40$, H\&E staining Figure 1D: Histological aspect of neuropathic diabetic foot ulcer.

The extracellular matrix here is ordinarily less dense than in ischemic diabetic foot ulcers. Thin collagen fibers appeared interconnected with fibrin material. The frame includes incipient capillaries with wall distortion, luminal occlusion and endothelial nuclear hypertrophy. As indicated by the arrow precocious wall thickening takes along the angiogenic process. As mentioned in the text, at this stage, relative fibroblast scarceness is detected. An apparently active secreting fibroblast is shown in the circle. Magnification x 40, H\&E staining.

\section{Gene expression differences between pressure and diabetic ulcers}

Differences in gene transcriptional expression were detected between pressure ulcers and diabetic foot ulcers samples. Table 3 shows only those genes with significant different expression.

EGFR and downstream signaling targets: A marginally lower although not significant difference $(p=0.07)$ of the EGFR gene expression was detected in the diabetic patients' samples as referred to pressure ulcers counterparts. A similar observation is applicable to AKT1 gene transcription ( $\mathrm{p}=0.06$ ). Surprisingly, the expression levels of PIK3CA and its antagonistic regulator PTEN were found very similar between diabetic and pressure ulcers ( $\mathrm{p}=0.12$ and 0.13 respectively). The metabolic master switch MTOR appeared far more underexpressed in diabetic ulcers than in pressure ulcers $(\mathrm{p}=0.001)$ which is expected given the theoretical anabolic depression of the cells in diabetes (Figure 2A).

Cell proliferation control: CCND1 expression appeared statistically similar between the two groups of wounds $(p=0.17)$. However the expression levels of other cell proliferation-promoting genes as CDK4, PCNA, and E2F1 appeared significantly depressed in diabetic ulcers as compared to pressure ulcers (all $\mathrm{p}<0.05)$ (Figures 2B-D). Furthermore, $c$-myc which is a well-renown cell proliferationcommitted transcription factor also exhibited a marginal reduction $(\mathrm{p}=0.06)$ in diabetic foot ulcers. Canonic cell cycle inhibitors as RB1 $(\mathrm{p}=0.55)$ and TP53 $(\mathrm{p}=0.177)$ showed no transcriptional differences between pressure and diabetic ulcers.
Extracellular matrix biology: Pressure ulcers exhibited far more gene transcriptional activity for COL1A1, COL3A1 and TGFB1 than diabetic ulcers (all $\mathrm{p} \leq$ 0.04) (Figure 3). No statistical differences were observed between the two ulcer groups for ILK gene expression $(\mathrm{p}=0.12)$.

Glucose metabolic pathways: A significant reduction in the expression of genes involved in glucose metabolic regulation in diabetic foot ulcers was detected in granulation tissue cells. Accordingly, INSR, SLC2A1, and enzymes as HK1 and HK2 isoforms, PFKP, PKM isoforms 1 and 2, and PDHA1 appeared significantly underexpressed in diabetic ulcers (all $\mathrm{p} \leq 0.03$ ) in relation to pressure ulcers. In biological line with the latest finding, PDK4 gene which downregulates $\mathrm{PDH}$, showed higher expression in diabetic ulcers than in pressure ulcers tissue $(\mathrm{p}=0.017)$ (Figure 4).

Survival and anabolism: No statistical differences were detected in FOXO1 gene transcription between diabetic and pressure ulcers $(\mathrm{p}=0.6)$. However it is notorious that $\mathrm{FOXO} 3$ gene appeared significantly underexpressed in diabetic granulation tissue as compared to pressure ulcers tissue $(\mathrm{p}=0.031)$ (Figure 5A). Again, in close biological correspondence, other metabolic regulator gene as SIRT1 exhibited significantly less expression in diabetic ulcers than in nondiabetic counterparts $(p=0.042)$ (Figure $5 B)$. Finally, no significant differences were noted for PPARG $(\mathrm{p}=0.88)$ nor PPARGC1 $(\mathrm{p}=0.088)$ gene expression between the two types of ulcers.

Anti-oxidant and anti-hypoxia defenses: SOD2 enzyme isoform 
Citation: Mendoza-Mari Y, Valdés-Pérez C, Rodríguez-Corrales E, Suárez-Alba J, García-Ojalvo A, et al. (2013) Histological and Transcriptional Expression differences between Diabetic Foot and Pressure Ulcers. J Diabetes Metab 4: 296. doi:10.4172/2155-6156.1000296

Page 6 of 11

\begin{tabular}{|c|c|c|c|c|c|c|c|c|c|}
\hline Gene & & Parameters & $\begin{array}{c}\text { Diabetic Foot Ulcers } \\
(n=9)\end{array}$ & $\begin{array}{l}\text { Pressure } \\
\text { Ulcers } \\
(n=5)\end{array}$ & $\begin{array}{l}\text { Acute } \\
\text { wound }\end{array}$ & $\begin{array}{l}\text { Dif. between } \\
\text { means (DFU- } \\
\text { PU) }\end{array}$ & (CI 95\%) & (Cl 99\%) & $p$ value \\
\hline \multirow{3}{*}{ MTOR } & \multirow{3}{*}{$\begin{array}{l}\text { Serine/threonine protein } \\
\text { kinase that regulates cell } \\
\text { growth, cell proliferation, cell } \\
\text { motility, cell survival, protein } \\
\text { synthesis, and transcription }\end{array}$} & Mean $\pm S D$ & $0.574 \pm 0.393$ & $1.422 \pm 0.288$ & 1.154 & \multirow{3}{*}{$-0.848 \pm 0.202$} & \multirow{3}{*}{$\begin{array}{l}-1.287 \text { to } \\
-0.409\end{array}$} & \multirow{3}{*}{$\begin{array}{l}-1.464 \text { to } \\
-0.232\end{array}$} & \multirow{3}{*}{$0.0012^{* *}$} \\
\hline & & $\begin{array}{l}\text { Median }(25 \% ; 75 \% \\
\text { percentile) }\end{array}$ & $0.517(0.169 ; 0.964)$ & $\begin{array}{c}1.266(1.193 \\
1.728)\end{array}$ & - & & & & \\
\hline & & $(\min ; \max )$ & $(0.047 ; 1.099)$ & $(1.126 ; 1.787)$ & - & & & & \\
\hline \multirow{3}{*}{$\mathrm{E} 2 \mathrm{~F} 1$} & \multirow{3}{*}{$\begin{array}{l}\text { Transcription factor. Plays a } \\
\text { crucial role in the control of } \\
\text { cell cycle and action of tumor } \\
\text { suppressor proteins }\end{array}$} & Mean \pm SD & $0.353 \pm 0.3381$ & $0.831 \pm 0.1878$ & 0.774 & \multirow{3}{*}{$-0.478 \pm 0.165$} & \multirow{3}{*}{$\begin{array}{l}-0.838 \text { to } \\
-0.117\end{array}$} & \multirow{3}{*}{$\begin{array}{c}-0.983 \text { to } \\
0.028\end{array}$} & \multirow{3}{*}{$0.0136^{*}$} \\
\hline & & $\begin{array}{l}\text { Median }(25 \% ; 75 \% \\
\text { percentile) }\end{array}$ & $0.304(0.033 ; 0.720)$ & $\begin{array}{l}0.728(0.724 \\
0.988)\end{array}$ & - & & & & \\
\hline & & $(\min ; \max )$ & $(0.001 ; 0.831)$ & $(0.724 ; 1.159)$ & - & & & & \\
\hline \multirow{3}{*}{ PCNA } & \multirow{3}{*}{$\begin{array}{l}\text { Cofactor of DNA polymerase } \\
\text { delta. Helps increase the } \\
\text { processivity of leading } \\
\text { strand synthesis during DNA } \\
\text { synthesis and repair }\end{array}$} & Mean \pm SD & $1.264 \pm 0.341$ & $1.737 \pm 0.496$ & 1.880 & \multirow{3}{*}{$-0.472 \pm 0.172$} & \multirow{3}{*}{$\begin{array}{l}-0.850 \text { to } \\
-0.094\end{array}$} & \multirow{3}{*}{$\begin{array}{c}-1.005 \text { to } \\
0.061\end{array}$} & \multirow{3}{*}{$0.019^{*}$} \\
\hline & & $\begin{array}{l}\text { Median }(25 \% ; 75 \% \\
\text { percentile) }\end{array}$ & $1.257(0.938 ; 1.510)$ & $\begin{array}{c}1.732(1.532 \\
1.944)\end{array}$ & - & & & & \\
\hline & & $(\min ; \max )$ & $(0.826 ; 1.849)$ & $(1.444 ; 1.955)$ & - & & & & \\
\hline \multirow{3}{*}{ CDK4 } & \multirow{3}{*}{$\begin{array}{l}\text { Catalytic subunit of the protein } \\
\text { kinase complex that leads } \mathrm{G} 1 \\
\text { to } \mathrm{S} \text { phase progression during } \\
\text { cell cycle }\end{array}$} & Mean \pm SD & $1.027 \pm 0.377$ & $1.412 \pm 0.150$ & 1.566 & \multirow{3}{*}{$-0.384 \pm 0.178$} & \multirow{3}{*}{$\begin{array}{c}-0.773 \text { to } \\
0.004\end{array}$} & \multirow{3}{*}{$\begin{array}{c}-0.930 \text { to } \\
0.160\end{array}$} & \multirow{3}{*}{$0.05^{*}$} \\
\hline & & $\begin{array}{l}\text { Median (25\%; } 75 \% \\
\text { percentile) }\end{array}$ & $1.145(0.816 ; 1.298)$ & $\begin{array}{l}1.440(1.288 \\
1.521)\end{array}$ & - & & & & \\
\hline & & $(\min ; \max )$ & $(0.197 ; 1.395)$ & $(1.156 ; 1.527)$ & - & & & & \\
\hline \multirow{3}{*}{ COL1A1 } & \multirow{3}{*}{$\begin{array}{l}\text { Fibrillar collagen found in } \\
\text { most connective tissues that } \\
\text { strengthens and supports many } \\
\text { tissues in the body, including } \\
\text { cartilage, bone, tendon, skin } \\
\text { and sclera }\end{array}$} & Mean \pm SD & $0.966 \pm 0.474$ & $1.448 \pm 0.117$ & 1.432 & & & & \\
\hline & & $\begin{array}{l}\text { Median }(25 \% ; 75 \% \\
\text { percentile) }\end{array}$ & $0.940(0.692 ; 1.336)$ & $\begin{array}{c}1.377(1.359 \\
1.572)\end{array}$ & - & $-0.482 \pm 0.166$ & $\begin{array}{l}-0.855 \text { to } \\
-0.109\end{array}$ & $\begin{array}{l}-1.015 \text { to } \\
0.050\end{array}$ & $0.016^{*}$ \\
\hline & & $(\min ; \max )$ & $(0.113 ; 1.670)$ & $(1.344 ; 1.606)$ & - & & & & \\
\hline & & Mean \pm SD & $0.937 \pm 0.392$ & $1.498 \pm 0.117$ & 1.421 & & & & \\
\hline COL3A1 & $\begin{array}{l}\text { it is produced quickly by young } \\
\text { fibroblasts before the tougher } \\
\text { type I collagen is synthesized. }\end{array}$ & $\begin{array}{l}\text { Median }(25 \% ; 75 \% \\
\text { percentile) }\end{array}$ & $1.138(0.568 ; 1.286)$ & $\begin{array}{c}1.451(1.410 \\
1.610)\end{array}$ & - & $-0.5606 \pm$ & -0.873 to & -1.005 to & $0.0025^{\star *}$ \\
\hline . & $\begin{array}{l}\text { Reticular fiber. Also found in } \\
\text { artery walls, skin, intestines and } \\
\text { the uterus }\end{array}$ & $(\min ; \max )$ & $(0.278 ; 1.360)$ & $(1.393 ; 1.685)$ & - & 0.1409 & -0.247 & -0.116 & $0.00<5$ \\
\hline & & Mean \pm SD & $1.266 \pm 0.524$ & $1.838 \pm 0.183$ & 2.065 & & & & \\
\hline & that regulates proliferation, & $\begin{array}{l}\text { Median }(25 \% ; 75 \% \\
\text { percentile) }\end{array}$ & $1.118(0.924 ; 1.782)$ & $\begin{array}{c}1.825(1.667 \\
2.015)\end{array}$ & - & & & & \\
\hline TGFB1 & $\begin{array}{l}\text { many cell types. TGF-beta is a } \\
\text { key regulator of ECM assembly } \\
\text { and remodeling. It inhibits } \\
\text { the synthesis of extracellular } \\
\text { proteinases while upregulating } \\
\text { the production of their inhibitors } \\
\text { and that of structural ECM } \\
\text { components, such as collagen }\end{array}$ & (min; max) & $(0.368 ; 1.876)$ & $(1.661 ; 2.093)$ & - & $-0.572 \pm 0.246$ & $\begin{array}{l}-1.107 \text { to } \\
-0.036\end{array}$ & $\begin{array}{c}-1.323 \text { to } \\
0.179\end{array}$ & $0.038^{*}$ \\
\hline & & Mean \pm SD & $0.626 \pm 0.375$ & $1.242 \pm 0.176$ & 1.282 & & & & \\
\hline INSR & $\begin{array}{l}\text { I ransmembrane receptor that } \\
\text { mediates the biological effects }\end{array}$ & $\begin{array}{l}\text { Median }(25 \% ; 75 \% \\
\text { percentile) }\end{array}$ & $0.643(0.258 ; 0.976)$ & $\begin{array}{c}1.184(1.110 \\
1.405)\end{array}$ & - & $-0.617 \pm 0.180$ & $\begin{array}{l}-1.009 \text { to } \\
-0.225\end{array}$ & $\begin{array}{l}-1.167 \text { to } \\
-0.067\end{array}$ & $0.005^{\star \star}$ \\
\hline & & $(\min ; \max )$ & $(0.131 ; 1.166)$ & $(1.075 ; 1.528)$ & - & & & & \\
\hline & Glucose transporter & Mean \pm SD & $0.684 \pm 0.420$ & $1.658 \pm 0.662$ & 1.172 & & & & \\
\hline SLC2A1 & $\begin{array}{l}\text { responsible for the low-level of } \\
\text { basal glucose uptake required }\end{array}$ & $\begin{array}{l}\text { Median }(25 \% ; 75 \% \\
\text { percentile) }\end{array}$ & $0.714(0.230 ; 1.077)$ & $\begin{array}{l}1.935(0.979 \\
2.200)\end{array}$ & - & $-0.974 \pm 0.286$ & $\begin{array}{l}-1.598 \text { to } \\
-0.350\end{array}$ & $\begin{array}{l}-1.849 \text { to } \\
-0.099\end{array}$ & $0.0053^{* *}$ \\
\hline & cells & $(\min ; \max )$ & $(0.082 ; 1.214)$ & $(0.697 ; 2.260)$ & - & & & & \\
\hline & Enzyme that localizes to & Mean \pm SD & $0.933 \pm 0.489$ & $1.996 \pm 0.385$ & 1.105 & & & & \\
\hline & $\begin{array}{l}\text { the outer membrane of } \\
\text { mitochondria, mediates }\end{array}$ & $\begin{array}{l}\text { Median }(25 \% ; 75 \% \\
\text { percentile) }\end{array}$ & $0.933(0.640 ; 1.346)$ & $\begin{array}{l}2.079(1.679 \\
2.273)\end{array}$ & - & & -1.619 to & -1.842 to & \\
\hline HK1 & $\begin{array}{l}\text { phosphorylation of glucose to } \\
\text { glucose-6-phosphate, the first } \\
\text { step in glucose metabolism } \\
\text { pathway }\end{array}$ & $(\min ; \max )$ & $(0.001 ; 1.587)$ & $(1.369 ; 2.413)$ & - & $-1.064 \pm 0.255$ & -0.509 & -0.286 & $0.0013^{\text {天 }}$ \\
\hline & Predominant form found in & Mean \pm SD & $0.945 \pm 0.457$ & $1.685 \pm 0.502$ & 0.926 & & & & \\
\hline HK2 & $\begin{array}{l}\text { skeletal muscle. Expression } \\
\text { studies suggest that it is } \\
\text { involved in the increased rate }\end{array}$ & $\begin{array}{l}\text { Median }(25 \% ; 75 \% \\
\text { percentile) }\end{array}$ & $0.916(0.536 ; 1.413)$ & $\begin{array}{l}1.702(1.203 \\
2.149)\end{array}$ & - & $-0.739 \pm 0.288$ & $\begin{array}{l}-1.382 \text { to } \\
-0.097\end{array}$ & $\begin{array}{l}-1.653 \text { to } \\
0.174\end{array}$ & $0.028^{*}$ \\
\hline & $\begin{array}{l}\text { of glycolysis seen in rapidly } \\
\text { growing cancer cells }\end{array}$ & $(\min ; \max )$ & $(0.279 ; 1.465)$ & $(1.056 ; 2.278)$ & - & & & & \\
\hline & & Mean \pm SD & $1.069 \pm 0.283$ & $1.426 \pm 0.227$ & 1.554 & & & & \\
\hline PFKP & of fructose-6-phosphate to & $\begin{array}{c}\text { Median (25\%; } 75 \% \\
\text { percentile) }\end{array}$ & $1.139(0.849 ; 1.259)$ & $\begin{array}{c}1.491(1.231 \\
1.588)\end{array}$ & - & $-0.357 \pm 0.148$ & $\begin{array}{l}-0.678 \text { to } \\
-0.035\end{array}$ & $\begin{array}{l}-0.809 \text { to } \\
0.095\end{array}$ & $0.032^{*}$ \\
\hline & & $(\min ; \max )$ & $(0.566 ; 1.465)$ & $(1.045 ; 1.630)$ & - & & & & \\
\hline
\end{tabular}


Citation: Mendoza-Mari Y, Valdés-Pérez C, Rodríguez-Corrales E, Suárez-Alba J, García-Ojalvo A, et al. (2013) Histological and Transcriptional Expression differences between Diabetic Foot and Pressure Ulcers. J Diabetes Metab 4: 296. doi:10.4172/2155-6156.1000296

Page 7 of 11

\begin{tabular}{|c|c|c|c|c|c|c|c|c|c|}
\hline \multirow[b]{3}{*}{ PKM1 } & \multirow{3}{*}{$\begin{array}{c}\text { Pyruvate kinase that } \\
\text { catalyzes the transfer of } \\
\text { a phosphoryl group from } \\
\text { phosphoenolpyruvate to } \\
\text { ADP, generating ATP and } \\
\text { pyruvate. The pyruvate kinase } \\
\text { isoforms PKM1 and PKM2 are } \\
\text { alternatively spliced products } \\
\text { of the PKM2 gene, from two } \\
\text { mutually exclusive exons }\end{array}$} & Mean \pm SD & $1.520 \pm 0.773$ & $2.915 \pm 0.728$ & 1.348 & \multirow[b]{3}{*}{$-1.395 \pm 0.423$} & \multirow[b]{3}{*}{$\begin{array}{l}-2.317 \text { to } \\
-0.474\end{array}$} & \multirow[b]{3}{*}{$\begin{array}{l}-2.688 \text { to } \\
-0.103\end{array}$} & \multirow[b]{3}{*}{$0.0064^{* *}$} \\
\hline & & $\begin{array}{l}\text { Median }(25 \% ; 75 \% \\
\text { percentile) }\end{array}$ & $1.804(1.014 ; 2.149)$ & $\begin{array}{l}3.071(2.220 \\
3.533)\end{array}$ & - & & & & \\
\hline & & $(\min ; \max )$ & $(0.001 ; 2.390)$ & $(1.792 ; 3.563)$ & - & & & & \\
\hline \multirow{3}{*}{ PKM2 } & \multirow{3}{*}{$\begin{array}{c}\text { The embryonic pyruvate } \\
\text { kinase M2 (PKM2) isoform is } \\
\text { highly expressed in human } \\
\text { cancer }\end{array}$} & Mean \pm SD & $1.095 \pm 0.417$ & $2.203 \pm 0.434$ & 1.684 & \multirow{3}{*}{$-1.108 \pm 0.236$} & \multirow{3}{*}{$\begin{array}{l}-1.622 \text { to } \\
-0.595\end{array}$} & \multirow{3}{*}{$\begin{array}{l}-1.828 \text { to } \\
-0.388\end{array}$} & \multirow{3}{*}{$0.0005^{\star \star \star}$} \\
\hline & & $\begin{array}{l}\text { Median }(25 \% ; 75 \% \\
\text { percentile) }\end{array}$ & $0.910(0.803 ; 1.466)$ & $\begin{array}{l}2.321(1.781 \\
2.566)\end{array}$ & - & & & & \\
\hline & & $(\min ; \max )$ & $(0.534 ; 1.796)$ & $(1.544 ; 2.625)$ & - & & & & \\
\hline \multirow[b]{3}{*}{ PDHA1 } & \multirow{3}{*}{$\begin{array}{c}\text { Enzyme of the pyruvate } \\
\text { dehydrogenase mitochondrial } \\
\text { multienzyme complex that } \\
\text { catalyzes conversion of } \\
\text { pyruvate to acetyl-CoA and } \\
\text { CO2, and provides the primary } \\
\text { link between glycolysis and } \\
\text { the tricarboxylic acid cycle }\end{array}$} & Mean \pm SD & $1.149 \pm 0.381$ & $2.025 \pm 0.235$ & 1.939 & \multirow[b]{3}{*}{$-0.876 \pm 0.189$} & \multirow[b]{3}{*}{$\begin{array}{c}-1.288 \text { to } \\
-0.463\end{array}$} & \multirow[b]{3}{*}{$\begin{array}{l}-1.454 \text { to } \\
-0.297\end{array}$} & \multirow[b]{3}{*}{$0.0006^{\star \star \star}$} \\
\hline & & $\begin{array}{l}\text { Median }(25 \% ; 75 \% \\
\text { percentile) }\end{array}$ & $1.220(0.944 ; 1.411)$ & $\begin{array}{l}2.016(1.793 \\
2.261)\end{array}$ & - & & & & \\
\hline & & $(\min ; \max )$ & $(0.325 ; 1.621)$ & $(1.770 ; 2.282)$ & - & & & & \\
\hline \multirow{3}{*}{ PDK4 } & \multirow{3}{*}{$\begin{array}{l}\text { Enzyme of the pyruvate } \\
\text { dehydrogenase mitochondrial } \\
\text { multienzyme complex } \\
\text { that inhibits the pyruvate } \\
\text { dehydrogenase complex by } \\
\text { phosphorylating PDH subunit }\end{array}$} & Mean \pm SD & $1.050 \pm 0.397$ & $0.457 \pm 0.226$ & 1.066 & \multirow{3}{*}{$0.538 \pm 0.195$} & \multirow{3}{*}{0.113 to 0.962} & \multirow{3}{*}{$\begin{array}{l}-0.057 \text { to } \\
1.132\end{array}$} & \multirow{3}{*}{$0.017^{*}$} \\
\hline & & $\begin{array}{l}\text { Median }(25 \% ; 75 \% \\
\text { percentile) }\end{array}$ & $0.796(0.722 ; 1.209)$ & $\begin{array}{l}0.520(0.208 \\
0.625)\end{array}$ & - & & & & \\
\hline & & $(\min ; \max )$ & $(0.437 ; 1.770)$ & $(0.202 ; 0.727)$ & - & & & & \\
\hline \multirow[b]{3}{*}{ FOXO3 } & \multirow{3}{*}{$\begin{array}{l}\text { Transcription factor which } \\
\text { triggers apoptosis through } \\
\text { expression of genes } \\
\text { necessary for cell death. It is } \\
\text { also implicated in resistance to } \\
\text { oxidative stress by promoting } \\
\text { the expression of anti-oxidant } \\
\text { defense enzymes such as Mn- } \\
\text { SOD and catalase }\end{array}$} & Mean \pm SD & $1.156 \pm 0.404$ & $1.516 \pm 0.114$ & 1.969 & \multirow[b]{3}{*}{$-0.360 \pm 0.144$} & \multirow[b]{3}{*}{$\begin{array}{l}-0.681 \text { to } \\
-0.039\end{array}$} & \multirow[b]{3}{*}{$\begin{array}{l}-0.816 \text { to } \\
0.096\end{array}$} & \multirow[b]{3}{*}{$0.0313^{*}$} \\
\hline & & $\begin{array}{l}\text { Median }(25 \% ; 75 \% \\
\text { percentile) }\end{array}$ & $1.172(1.013 ; 1.452)$ & $\begin{array}{c}1.515(1.417 \\
1.616)\end{array}$ & - & & & & \\
\hline & & $(\min ; \max )$ & $(0.243 ; 1.633)$ & $(1.340 ; 1.628)$ & - & & & & \\
\hline \multirow{3}{*}{ SIRT1 } & \multirow{3}{*}{$\begin{array}{l}\text { Histone deacetylase type III, } \\
\text { deacetylates a broad number } \\
\text { of nonhistone substrates in a } \\
\text { variety of tissues, activating } \\
\text { or silencing their biological } \\
\text { activities }\end{array}$} & Mean \pm SD & $0.373 \pm 0.152$ & $0.853 \pm 0.371$ & 0.813 & \multirow{3}{*}{$-0.478 \pm 0.173$} & \multirow{3}{*}{$\begin{array}{l}-0.931 \text { to } \\
-0.026\end{array}$} & & \\
\hline & & $\begin{array}{l}\text { Median }(25 \% ; 75 \% \\
\text { percentile) }\end{array}$ & $0.339(0.250 ; 0.482)$ & $\begin{array}{l}0.836(0.527 \\
1.188)\end{array}$ & - & & & $\begin{array}{c}-1.196 \text { to } \\
0.239\end{array}$ & $0.042^{*}$ \\
\hline & & $(\min ; \max )$ & $(0.168 ; 0.643)$ & $(0.513 ; 1.425)$ & - & & & & \\
\hline & One the most important & Mean \pm SD & $1.382 \pm 0.232$ & $1.686 \pm 0.176$ & 2.281 & & & & \\
\hline & $\begin{array}{l}\text { enzymes for anti-oxidant } \\
\text { defense. This is a }\end{array}$ & $\begin{array}{l}\text { Median }(25 \% ; 75 \% \\
\text { percentile) }\end{array}$ & $1.294(1.188 ; 1.565)$ & $\begin{array}{l}1.750(1.510 \\
1.829)\end{array}$ & - & & & & \\
\hline SOD2 & $\begin{array}{l}\text { that catalyses the dismutation } \\
\text { of toxic superoxide ion into } \\
\text { hydrogen peroxide and } \\
\text { diatomic oxygen }\end{array}$ & $(\min ; \max )$ & $(1.070 ; 1.782)$ & $(1.430 ; 1.875)$ & - & $-0.304 \pm 0.120$ & -0.043 & 0.062 & $0.026^{*}$ \\
\hline
\end{tabular}

Gene expression was assessed by semi-quantitative RT-PCR and normalized to ribosomal subunit 18S mRNA. SD: Standard Deviation; min: Minimum; max: Maximum; dif: Difference; Cl: Confidence Interval. ${ }^{*} p<0.05,{ }^{* *} p<0.01,{ }^{* *} p<0.001$.

Table 3: Relative gene expression in diabetic foot ulcers, pressure ulcers and acute wound

exhibited significantly higher transcriptional activity in pressure ulcers than in diabetic ulcers $(\mathrm{p}=0.026)$ (Figure $5 \mathrm{C})$. No statistical differences were observed in HIF1A gene between the two ulcers populations $(\mathrm{p}=0.9)$.

Pro-inflammatory response: TNF gene expression levels were similar in both forms of chronic wounds $(\mathrm{p}=0.9)$.

\section{Discussion}

The factors that "wipe away" from the cells the intrinsic mechanisms for a physiological repair and consequently lead to wound chronification remain unclear. In an attempt to gain further insights into the biology of chronic wounds, we have characterized the histology and compared the transcriptional activity of various wound healing-relevant genes, between diabetic and pressure ulcers as clinical paradigms of pernicious ulcers. The major limitation of this work resides in the reduced number of samples of chronic ulcers studied. Yet, the donor patients were rigorously selected so that they were representative of elemental features as ethnic homogeneity, long data of basic disease, wound chronicity and metabolic control for the case of diabetics. An additional limitation we confronted is the lack of "control" granulation tissue samples from acute, full-thickness wounds derived from nondiabetic, age-matched healthy donors. This has therefore restricted our views on the transcriptional activity of the genes studied in acute wounds from healthy subjects and excluded the possibility of statistical comparisons as a single acute wound sample was obtained. Thus, this control wound sample included is used solely as a limited reference.

As previously mentioned, we found that although a stagnant granulation process is a common factor for diabetic and pressure ulcers, each type of ulcer shows a particular morphological imprinting, thus establishing differences between pressure ulcers, diabetic-ischemic and diabetic-neuropathic; so that the two later classes appear as histological unrelated entities. The early onset of dense fibrotic matrix made up by thick collagen fibers had been previously described in pressure ulcers 
Citation: Mendoza-Mari Y, Valdés-Pérez C, Rodríguez-Corrales E, Suárez-Alba J, García-Ojalvo A, et al. (2013) Histological and Transcriptional Expression differences between Diabetic Foot and Pressure Ulcers. J Diabetes Metab 4: 296. doi:10.4172/2155-6156.1000296
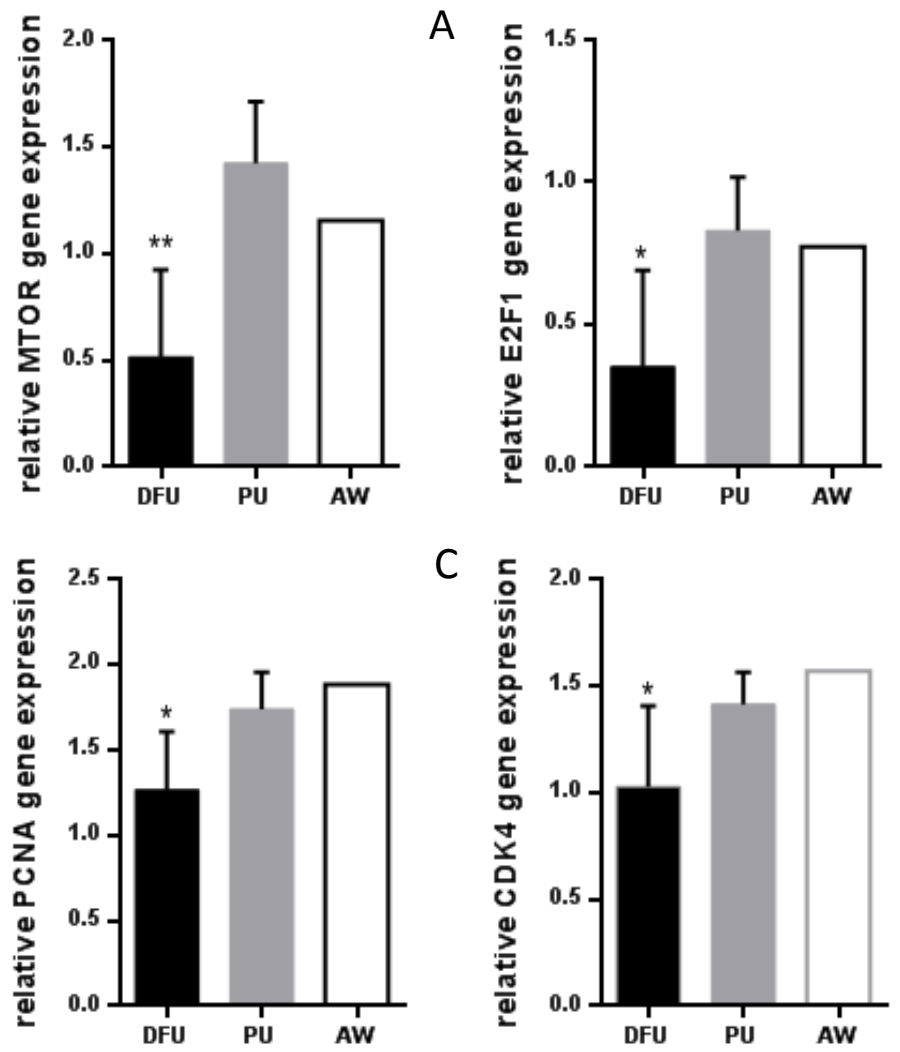

Figure 2: Relative gene expression in diabetic foot ulcers (solid bar), pressure ulcers (grey bar) and acute wound (open bar) of MTOR (A), E2F1 (B), PCNA (C) and CDK4 (D).

Gene expression was assessed by semi-quantitative RT-PCR and normalized to ribosomal subunit $18 \mathrm{~S}$ mRNA. Data are presented as mean \pm standard deviation. ${ }^{*} p<0.05,{ }^{* *} p<0.01$
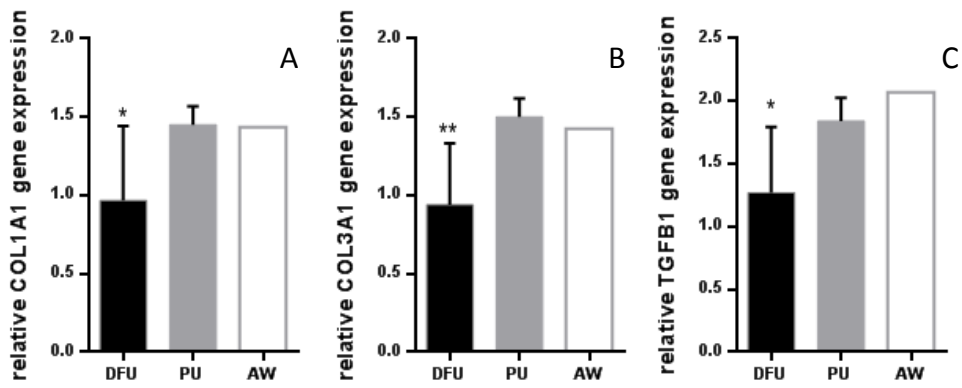

Figure 3: Relative gene expression in diabetic foot ulcers (solid bar), pressure ulcers (grey bar) and acute wound (open bar) of COL1A1 (A), COL3A1 (B), and TGFB1 (C)

Gene expression was assessed by semi-quantitative RT-PCR and normalized to ribosomal subunit $18 \mathrm{~S}$ mRA. Data are presented as mean \pm standard deviation. ${ }^{*} p<0.05,{ }^{* *} p<0.01$

[13]. However the driving forces behind this morphological appearance does not seem to be clarified. Whether these microstructural changes are a consequence of constant/repeated cutaneous pressure [14]; a sort of "lasting mechanical memory" could then be hypothesized as pressurerelief does not acutely restores the physiological healing trajectory [15]. An intriguing qualitative finding is that this fibroplastic induration appeared inversely correlated with the local fibroblast population, suggesting an imbalance between a consolidated fibrotic matrix and the matrix-producing cells. The fact that pressure ulcers-cultured fibroblasts exhibit a short replicative life becoming prematurely senescent [16] and that these cells are "homed" into a pro-apoptotogenic environment [5] incite to speculate that these wounds become "stalled" within the fibrogenic phase with no subsequent turnover or remodeling by a deficit of healthy effector cells. Globally speaking, fibroblasts dysfunction and apoptosis appear as pivotal factors toward wound chronification [17]. Although still persists scarcity of literature focusing on the histopathology of pressure ulcers [18], previous descriptions include an intense immune-inflammatory infiltrate [13]. Contradictorily, we 

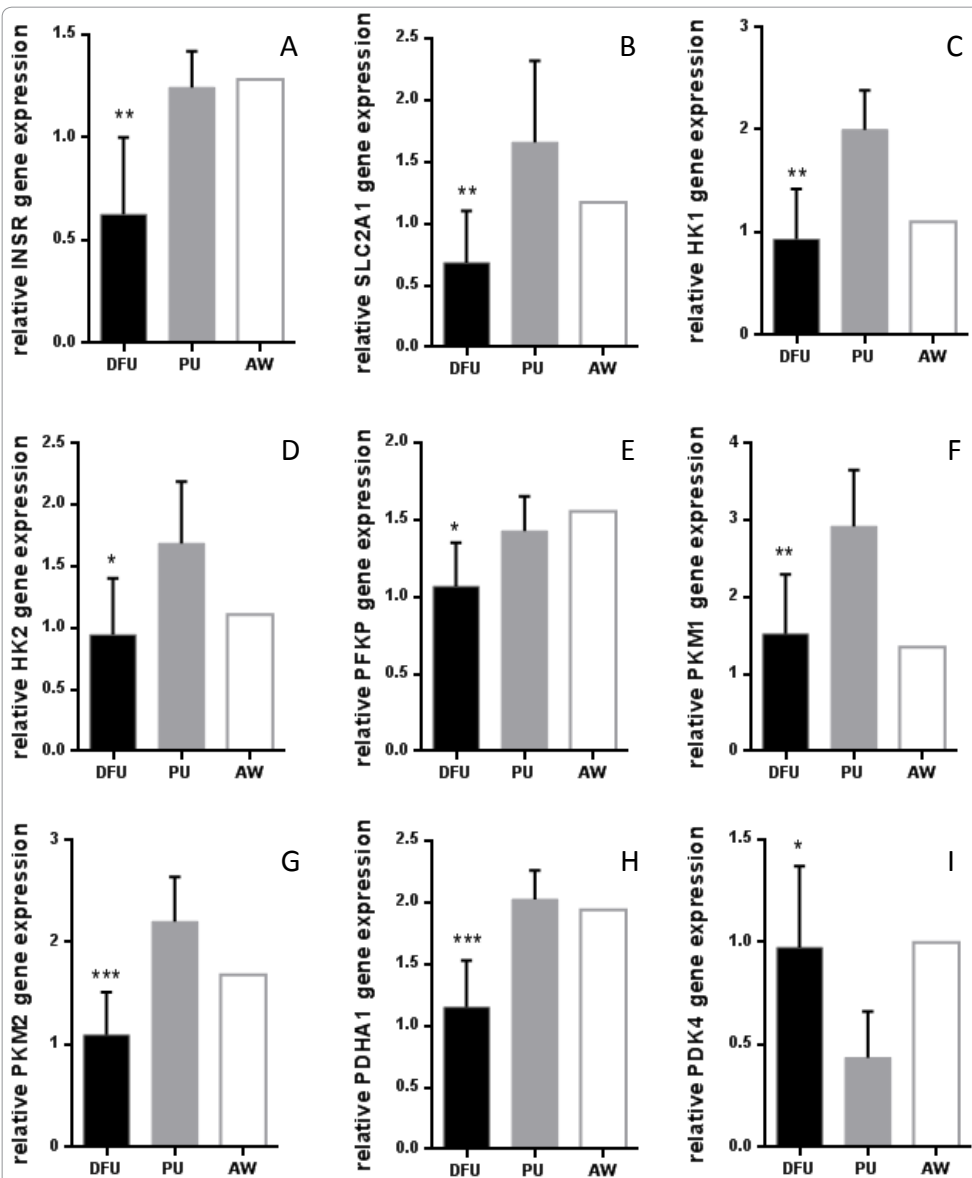

Figure 4: Relative gene expression in diabetic foot ulcers (solid bar), pressure ulcers (grey bar) and acute wound (open bar) of INSR (A), SLC2A1 (B), HK1 (C), HK2 (D), PFKP (E), PKM1 (F), PKM2 (G), PDHA1 (H) and PDK4 (I).

Gene expression was assessed by semi-quantitative RT-PCR and normalized to ribosomal subunit $18 \mathrm{~S}$ mRNA. Data are presented as mean \pm standard deviation. ${ }^{*} p<0.05,{ }^{* *} p<0.01,{ }^{* \star *} p<0.001$
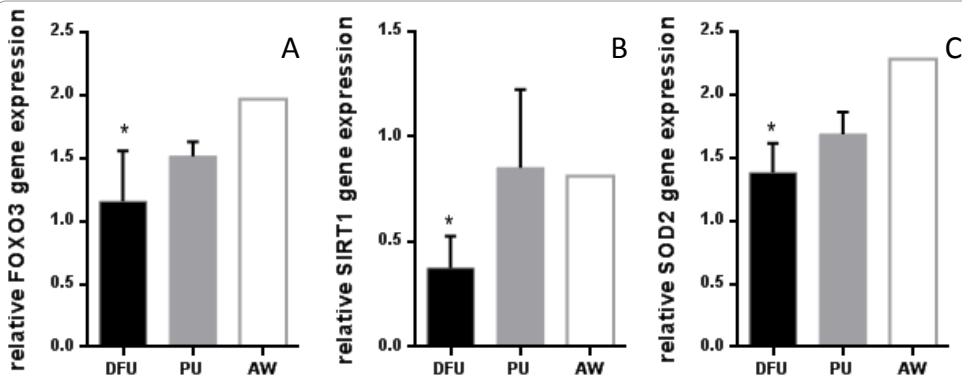

Figure 5: Relative gene expression in diabetic foot ulcers (solid bar), pressure ulcers (grey bar) and acute wound (open bar) of FOXO3 (A), SIRT1 (B) and SOD2 (C). Gene expression was assessed by semi-quantitative RT-PCR and normalized to ribosomal subunit $18 \mathrm{~S}$ mRN. Data are presented as mean \pm standard deviation. ${ }^{*} p<0.05$.

rarely detected inflammatory infiltration across the microscopic fields. This discrepancy may be related to the characteristics of our study population: solely male, relatively younger, and non-emaciated subjects with spinal cord trauma as a basic condition, versus other studies based on elderly/debilitated patients [19].

Although persistent hyperglycemia is the common and proximal factor that disrupts fibroblasts, pericytes, keratinocytes and endothelial cells physiology thus hindering wound healing in diabetics [20,21]; it became clear that foot ulcer ethiopathogenic component (ischemic or neuropathic) is associated to a privative granulation tissue histopathological image. This finding may be a contribution of this work. To the best of our knowledge only Loots et al. [22] and Piaggessi et al. [23] had conducted histopathological studies of diabetic ulcers describing only the neuropathic lesions as "frozen" in a chronic low- 
Citation: Mendoza-Mari Y, Valdés-Pérez C, Rodríguez-Corrales E, Suárez-Alba J, García-Ojalvo A, et al. (2013) Histological and Transcriptional Expression differences between Diabetic Foot and Pressure Ulcers. J Diabetes Metab 4: 296. doi:10.4172/2155-6156.1000296

grade inflammatory state associated to a scarce provisional extracellular matrix. These studies did not include ischemics-derived samples. The mechanisms mediating the differences of each type of extracellular matrix, angiogenic response, its organization and density; and even in fibroblasts cytology appear far to be elucidated. Similarly, it remains to be explained how and why, long-term evolution events like diabetic microvascular disease (i.e., media thickening or neointimal hypertrophy) can be so rapidly recreated by a growing neovessel within an incipient granulation tissue. Since the most aberrant morphological changes we found emerged from ischemic granulation tissue samples; hypoxia and its downstream biochemical disturbances could be raised as an instrumental ethiopathogenic ingredient for these vascular aberrancies.

The data derived from statistical comparisons described above indicate that the expression of different functional classes of genes, appear far more affected in diabetic patients ulcer cells rather than in decubitus ulcers counterparts. EGFR and some of its downstream phosphorylation targets were selected as paradigms of tyrosine kinase signaling pathways which may be disrupted by hyperglycemia [24]. Globally speaking our evidences support the notion that these pathways are dysfunctional in diabetic wound cells as compared to decubitus ulcers. This alteration has been attributed to glucose toxicity, receptors' non-enzymatic glycation or by the local inflammation $[10,25,26]$ all of which appear to reduce kinase receptors phosphorylation activation. Furthermore, although we found no significant differences in the expression of two major cell proliferation cycle inhibitors (TP53 and RB1) between diabetic and pressure ulcers; critical mitosis promoters as CDK4, PCNA and E2F1 appeared underexpressed by diabetic wound cells. CDK4 and PCNA expression failure have been previously invoked as molecular markers of chronic wounds fibroblasts proliferation reluctance $[27,28]$. In line with these findings is that TGF- $\beta 1$ appears significantly down-regulated in diabetic ulcers as compared to pressure ulcers. This growth factor is a well-reputed actor for fibroblasts proliferation, migration and secretion, which offers theoretical explanation for the remarkable transcriptional reduction in collagens I and III as for the fibroblasts proliferation promoters, observed in the diabetic wound samples [29]. As curious note with no major biological translation, the expression of all the above mentioned genes was arithmetically similar between pressure ulcers and the single acutewound granulation tissue sample.

Perhaps, the most relevant contribution of this work with no previous anticipation in the field; is that we found that diabetic granulation tissue cells, although "de novo" cells exhibit a sort of "genetic or epigenetic imprinting" for the deranged expression of glucose-metabolism related genes which have been largely implicated in type-2 diabetes pathophysiology [30]. As compared to decubitus ulcers, diabetic wound cells express far less insulin receptor, hexokinase isoforms 1 and 2, phosphofructokinase, pyruvate kinase isoforms 1 and 2, pyruvate dehydrogenase, and significantly more of its inhibitor enzyme pyruvate dehydrogenase kinase isoform 4. Interestingly, all of them have been considered as molecular markers of insulin resistance, glucose intolerance and predictors for the onset of type- 2 diabetes [30]. Most remarkable is the fact that all of these and other genes deregulations had solely been described in the liver, skeletal muscle and adipose tissue as the most important glucose consumers and major insulin targets [30-32]. Thus, for the first time it is shown that a transient, de novo multicellular material, as the diabetic granulation tissue, somewhat "inherits" and reflects the same molecular derangements detected in the most important glucose clearance tissues/organs. In other words, granulation tissue, despite its early age, is also a diabetic tissue. Again, and as a curious comment, all these genes exhibit similar expression between decubitus granulation tissue and the single-acute granulation tissue control sample; suggesting that the above described derangements are diabetics' privative traits.

Although we found no differences between pressure and diabetic ulcers in critical genes involved in energy homeostasis and cytoprotection as PPARG and PPARGC1; a complementary finding around the metabolic disorders that prevail in diabetic granulation tissue is the significant underexpression of other important genes such as FOXO3 and SIRT1. The observation that SOD2 expression is significantly lower in diabetic granulation tissue, may contribute to explain the welldescribed pathogenic role of the pro-oxidant environment in diabetic complications [33]. The fact that FOXO transcription factors reduce the level of oxidative stress by the transcriptional induction of SOD [34] may assist us to explain why SOD2 appeared underexpressed in diabetic wound samples. A meaningful finding to suggest that diabetic granulation tissue cells may be under a negative pro-anabolic and energetic balance is supported by the complementary underexpression of SIRT1. SIRT1 is known to regulate metabolism, to stimulate mitochondrial protein synthesis and activity, as to selectively regulate FOXO to certain targets genes involved in cells self-defense [35]. Taken together these data incite to suggest that diabetic foot ulcer cells may be endowed with a myriad of molecular disorders that may encompass from insulin receptor underexpression to mitochondrial functional failure.

This study, has allowed for a more comprehensive idea of the intrinsic histological aspects of different types of chronic ulcers, has offered a broader notion of the transcriptional profile of wound healing and metabolically-relevant genes, and has further strengthened our hypothesis that wound chronification is a distal destiny reachable from different or alternative roads. It has the merit to show for the first time that not only the major glucose-clearance organs, but the young-aged granulation tissue cells also exhibit a molecular "imprinting" toward glucose homeostasis failure. Moreover, we still miss however to gain a major enlightening on the core of pressure ulcers pathobiology.

\section{References}

1. Pfeffer F, von Dobschuetz E, Riediger H, Moosmann C, Hopt UT (2004) [The non-healing wound]. MMW Fortschr Med 146: 45-48.

2. Cordeiro MB, Antonelli EJ, da Cunha DF, Júnior AA, Júnior VR, et al. (2005) Oxidative stress and acute-phase response in patients with pressure sores. Nutrition 21: 901-907.

3. Levine JM (1992) Historical notes on pressure ulcers: the cure of Ambrose Paré. Decubitus 5: 23-24, 26.

4. Jaul E (2010) Assessment and management of pressure ulcers in the elderly: current strategies. Drugs Aging 27: 311-325.

5. Jiang L, Zhang E, Yang Y, Zhang C, Fu X, et al. (2012) Effectiveness of apoptotic factors expressed on the wounds of patients with stage III pressure ulcers. J Wound Ostomy Continence Nurs 39: 391-396.

6. Yager DR, Zhang LY, Liang HX, Diegelmann RF, Cohen IK (1996) Wound fluids from human pressure ulcers contain elevated matrix metalloproteinase levels and activity compared to surgical wound fluids. J Invest Dermatol 107: 743-748.

7. Cruse JM, Wang H, Lewis RE, Cespedes J, Morrison RS 3rd, et al. (2002) Cellular and molecular alterations in spinal cord injury patients with pressure ulcers: a preliminary report. Exp Mol Pathol 72: 124-131.

8. Sisco M, Liu WR, Kryger ZB, Mustoe TA (2007) Reduced up-regulation of cytoprotective genes in rat cutaneous tissue during the second cycle of ischemia-reperfusion. Wound Repair Regen 15: 203-212.

9. Berlanga J, Valdéz C, Savigne W, Mendoza Y, Franco N, et al. (2010) Cellular and molecular insights into the wound healing mechanism in diabetes. Biotecnología Aplicada 27: 255-261. 
Citation: Mendoza-Mari Y, Valdés-Pérez C, Rodríguez-Corrales E, Suárez-Alba J, García-Ojalvo A, et al. (2013) Histological and Transcriptional Expression differences between Diabetic Foot and Pressure Ulcers. J Diabetes Metab 4: 296. doi:10.4172/2155-6156.1000296

10. Berlanga-Acosta JB, Schultz GS, López-Mola E, Guillén-Nieto GE, GarcíaSiverio M, et al. (2013) Glucose Toxic Effects on Granulation Tissue Productive Cells: The Diabetics' Impaired Healing. Biomed Research International.

11. (2000) National Pressure Ulcer Advisory Panel: Pressure ulcer definition and etiology.

12. Armstrong DG, Lavery LA (1998) Diabetic foot ulcers: prevention, diagnosis and classification. Am Fam Physician 57: 1325-1332, 1337-8.

13. Vande Berg JS, Rudolph R (1995) Pressure (decubitus) ulcer: variation in histopathology--a light and electron microscope study. Hum Pathol 26: 195200.

14. Huang L, Nakagami G, Minematsu T, Kinoshita A, Sugama J, et al. (2010) Ulceration and Delayed Healing Following Pressure Loading in Hyperglycemic Rats With an Immature Dermal Collagen Fiber Network. Wounds 22: 237-244.

15. Edsberg LE, Cutway R, Anain S, Natiella JR (2000) Microstructural and mechanical characterization of human tissue at and adjacent to pressure ulcers. J Rehabil Res Dev 37: 463-471.

16. Vande Berg JS, Rose MA, Haywood-Reid PL, Rudolph R, Payne WG, et al. (2005) Cultured pressure ulcer fibroblasts show replicative senescence with elevated production of plasmin, plasminogen activator inhibitor-1, and transforming growth factor-beta1. Wound Repair Regen 13: 76-83.

17. Wall IB, Moseley R, Baird DM, Kipling D, Giles P, et al. (2008) Fibroblast dysfunction is a key factor in the non-healing of chronic venous leg ulcers. Invest Dermatol 128: 2526-2540.

18. Edsberg LE (2007) Pressure ulcer tissue histology: an appraisal of current knowledge. Ostomy Wound Manage 53: 40-49.

19. Seiler WO, Stähelin HB (1986) Recent findings on decubitus ulcer pathology: implications for care. Geriatrics 41: 47-50, 53-7, 60.

20. Stojadinovic O, Brem H, Vouthounis C, Lee B, Fallon J, et al. (2005) Molecular pathogenesis of chronic wounds: the role of beta-catenin and c-myc in the inhibition of epithelialization and wound healing. Am J Pathol 167: 59-69.

21. Tomic-Canic M, Ayello EA, Stojadinovic O, Golinko MS, Brem H (2008) Using gene transcription patterns (bar coding scans) to guide wound debridement and healing. Adv Skin Wound Care 21: 487-492.

22. Loots MA, Lamme EN, Zeegelaar J, Mekkes JR, Bos JD, et al. (1998) Differences in cellular infiltrate and extracellular matrix of chronic diabetic and venous ulcers versus acute wounds. J Invest Dermatol 111: 850-857.
23. Piaggesi A, Viacava P, Rizzo L, Naccarato G, Baccetti F, et al. (2003) Semiquantitative analysis of the histopathological features of the neuropathic foot ulcer: effects of pressure relief. Diabetes Care 26: 3123-3128.

24. Bazley LA, Gullick WJ (2005) The epidermal growth factor receptor family. Endocr Relat Cancer 12: S17-27.

25. Hehenberger K, Hansson A (1997) High glucose-induced growth factor resistance in human fibroblasts can be reversed by antioxidants and protein kinase C-inhibitors. Cell Biochem Funct 15: 197-201.

26. Lamers ML, Almeida ME, Vicente-Manzanares M, Horwitz AF, Santos MF (2011) High glucose-mediated oxidative stress impairs cell migration. PLoS One 6: e22865.

27. Vande Berg JS, Rose MA, Payne WG, Haywood-Reid PL, Robson MC (2003) Significance of cell cycle for wound stratification in clinical trials: analysis of a pressure ulcer clinical trial utilizing cyclin D/cdk4. Wound Repair Regen 11 : $11-18$.

28. Wang CJ, Ko JY, Kuo YR, Yang YJ (2011) Molecular changes in diabetic foot ulcers. Diabetes Res Clin Pract 94: 105-110.

29. Mi Q, Rivière B, Clermont G, Steed DL, Vodovotz Y (2007) Agent-based mode of inflammation and wound healing: insights into diabetic foot ulcer pathology and the role of transforming growth factor-beta1. Wound Repair Regen 15: 671682

30. Bouché C, Serdy S, Kahn CR, Goldfine AB (2004) The cellular fate of glucose and its relevance in type 2 diabetes. Endocr Rev 25: 807-830.

31. Taniguchi CM, Emanuelli B, Kahn CR (2006) Critical nodes in signalling pathways: insights into insulin action. Nat Rev Mol Cell Biol 7: 85-96.

32. Roussel D, Dumas JF, Simard G, Malthièry Y, Ritz $P(2004)$ Kinetics and contro of oxidative phosphorylation in rat liver mitochondria after dexamethasone treatment. Biochem J 382: 491-499.

33. Giacco F, Brownlee M (2010) Oxidative stress and diabetic complications. Circ Res 107: 1058-1070.

34. Kops GJ, Dansen TB, Polderman PE, Saarloos I, Wirtz KW, et al. (2002) Forkhead transcription factor FOXO3a protects quiescent cells from oxidative stress. Nature 419: 316-321.

35. Brunet A, Sweeney LB, Sturgill JF, Chua KF, Greer PL, et al. (2004) Stress dependent regulation of FOXO transcription factors by the SIRT1 deacetylase. Science 303: 2011-2015. 